\title{
Handelshochschule Berlin.
}

\section{Vorlesungen und Übungen}

\section{in Sommer-Semester 1910.}

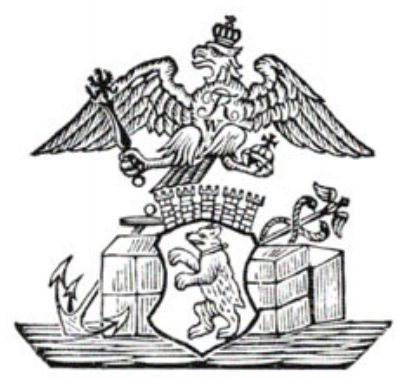

Preis 30 Pf $\mathrm{Zu}$ haben belm Pedell in der Pfortner-Loge des Hochschulgebãudes (am Eingang Spandauerstr. 1). 